IRSH 56 (20II), pp. 7I-IOI doi:I0.10I7/S00208590100007I 4

(C) 20I I Internationaal Instituut voor Sociale Geschiedenis

\title{
Friendly Societies, Commercial Insurance, and the State in Sickness Risk Coverage: The Case of Spain (1880-1944)
}

\author{
JER ÒNIA PONS PONS \\ Faculty of Economic Sciences and Business Studies, \\ University of Seville
}

E-mail: jpons@us.es

\author{
MARGARITA VIL A R R O RÍGUEZ \\ Faculty of Economic Sciences and Business Studies, \\ University of A Coruna \\ E-mail: mvilar@udc.es
}

\begin{abstract}
SUMmARY: The main aim of this paper is to analyse the singularity of the Spanish position with regard to coverage of the risk of sickness within the context of the different welfare models described in international literature. This analysis enables us to verify that in Spain, as in other countries, there were initially different forms of sickness coverage which coexisted, created by the market, by workers themselves and, gradually, by the state. Within this so-called mixed economy of welfare, the most extensive health coverage for the Spanish population was a result of the self-organization of workers, and this continued until the Civil War (1936-1939), not so much due to its efficacy and viability, as to the slow development of private insurance companies and the inability of the state to implement compulsory sickness insurance. The installation of the Franco dictatorship meant that the introduction of compulsory sickness insurance was further delayed, and when it was eventually passed, it offered only limited coverage, was enacted more for political than for social ends, and was to result in the virtual disappearance of friendly societies.
\end{abstract}

\section{INTRODUCTION}

From a historical point of view, the advent of industrialization entailed the application of new technologies and the emergence of business opportunities, processes which existed side by side with an industrial 
proletariat subjected to harsh working and living conditions. ${ }^{I}$ Besides problems of overcrowding and poor hygiene and sanitation, workers had to fight against the economic insecurity stemming from sickness, old age, industrial accidents, or unemployment, any of which could prevent them from earning a wage; their only source of survival. ${ }^{2}$ During these early stages, coverage for social risks came from four basic sectors: the state, the market, family companies, and solidarity among workers. However, we also find insurance mutuals promoted by workers or employers, tradeunion activity and, of course, family networks, all of which offered complementary solutions to the economic uncertainties deriving from the capitalist system. The scenario depicted above represents what some authors have termed "the mixed economy of welfare". ${ }^{3}$

The process of industrialization in Spain in the nineteenth century progressed much more slowly than in other European countries. Various causes have been recorded that help to explain Spain's "relative backwardness", the most notable of these being underdevelopment in agriculture, a lack of resources accumulated through taxation, the insufficient intellectual and technical preparation of the population, the loss of the last colonial territories in the war of 1898 , and the lack of incentives for competition within a protectionist framework. ${ }^{4}$ Far from being isolated issues, it is the sum of all these factors that helps to explain the complexity of Spain's backwardness at the start of the twentieth century. This backwardness was also reflected in the late maturity of the country's socio-political structures, which delayed the intervention of Spanish governments in social issues.

Within this context, the Spanish liberal state offered workers two rather unsatisfactory options for dealing with social risks: personal savings or charity. However, saving proved to be a basically unviable option for workers, whose household budgets were tight at the beginning of industrialization, even if none of the family members were out of work. ${ }^{5}$

I. Ricardo Campos, Curar y gobernar. Medicina y liberalismo en la España del siglo XIX (Madrid, 2003).

2. Antonio Martín Valverde, "La formación del Derecho del Trabajo en España. Introducción", in idem et al. (eds), La legislación social en la Historia de España. De la Revolución Liberal a I936 (Madrid, 1987), pp. xv-cxiv.

3. Bernard Harris and Paul Bridgen, Charity and Mutual Aid in Europe and North Amercia since I 800 (New York, 2007), p. I.

4. For other explanations which refer to the possibilities of emigrating or to the fact that Spain did not participate in the gold standard system, see Albert Carreras and Xavier Tafunell, Historia económica de la España Contemporánea (Barcelona, 2004), pp. 208-22 I.

5. David S. Reher and Enriqueta Camps, "Las economías familiares dentro de un contexto histórico comparado", Reis, 55 (1991), pp. 65-91; Enriqueta Camps, "Trabajo infantil y estrategias familiares durante los primeros estadios de la industrialización catalana (1850-1925). Esbozos a partir del estudio de un caso", Cuadernos de Historia Contemporánea, 24 (2002), pp. 263-279. 
The situation became even worse if the frequent instance of sickness or unemployment ended up undermining the fragile financial equilibrium of workers' homes. As far as charity was concerned, this was only provided for families registered in the "census of the poor". Generally speaking, charity could not count on significant public resources and depended, rather, on the goodwill of private donors. ${ }^{6}$ The rest of the population was denied access to free hospital care and charity, and depended on pecuniary medical benefits. Under such conditions, workers suffering from longterm illnesses fell into a state of exclusion and marginality, giving rise to new categories of poverty to which the traditional cliché of "vagrants and crooks" no longer applied. ${ }^{7}$

The poor conditions in terms of diet and hygiene and the difficulties in gaining access to medical and pharmaceutical services made the sicknesspoverty-death link one of the main fears of the nineteenth-century urban working classes. ${ }^{8}$ In spite of social fears, governments did not start to regulate legally sickness insurance until the end of the nineteenth century. During a good part of this century, private insurance companies also failed to satisfy the demands of working-class families for healthcare, as in most countries. This was, first of all, because the premiums were in many cases beyond the financial reach of wage-earners, and further because the sector was very little developed. Additional contributory factors were the cases of bankruptcy associated with the financial crises of the period and the obscurity of the existing legislative framework, which led to a lack of confidence among the population in respect of commercial insurance companies. ${ }^{9}$ Within this context, workers looked for responses to the social failings of the market through formulas of solidarity and greater autonomy. ${ }^{\text {IO }}$ Through the creation of non-profit making voluntary

6. Conferencia Nacional de Seguros de Enfermedad, Invalidez y Maternidad, Reivindicaciones legales y económicas de las sociedades de socorros mutuos (Madrid, 1922); Francisco Comín, Historia de la Hacienda Pública II. España (I808-I995) (Barcelona, I996), p. 253.

7. Elena Maza, Pobreza y beneficencia en la España contemporánea (I808-1936) (Barcelona, 1999); Estrella López Keller, "Hacia la quiebra de la mentalidad liberal; las resistencias al cambio", in Ministerio de Trabajo y Asuntos Sociales, Historia de la acción social pública en España. Beneficencia y Previsión (Madrid, 1990), pp. I37-160.

8. In fact, John Murray comments that medical advances and increasingly costly medicines reduced the ability of workers to protect themselves using their own resources. See John E. Murray, "The Persistence of the Health Insurance Dilemma", Social Science History, 30 (2006), pp. $465-477$.

9. David T. Beito, From Mutual Aid to the Welfare State: Fraternal Societies and Social Services, I890-I967 (Chapel Hill, NC, 2000), p. I4.

I0. Daniel Weinbren, "Supporting Self-Help, Charity, Mutuality and Reciprocity in NineteethCentury Britain", in Harris and Bridgen, Charity and Mutual Aid, pp. 67-88; Marcel van der Linden (ed.), Social Security Mutualism: The Comparative History of Mutual Benefit Societies (Bern, I996); Marco H.D. van Leeuwen, "Historical Welfare Economics in the Nineteenth Century: Mutual Aid and Private Insurance for Burial, Sickness, Old Age, 
associations, the insured, who acted at the same time as insurers and administrators, received aid from common funds in response to the situations of risk established in their statutes.

In Spain's case, a state welfare system started to take shape in the early twentieth century with the establishment of old age, maternity, and industrial accident insurances. Given this situation, the provision of sickness insurance seemed to be just a matter of time. However, its approval was delayed until the I940s, making Spain one of the last European countries to have compulsory sickness insurance. Consequently, the lifespan of the so-called mixed economy of welfare in the area of health coverage was longer in Spain and lasted until later, at least until the Civil War (1936-1939). Within the mixed economy of welfare, the most extensive health coverage for the Spanish population was a result of the self-organization of workers, and this continued up to the Civil War, not so much due to its efficacy and viability as to the slow development of private insurance companies and the inability of the state to implement compulsory sickness insurance. Meanwhile, on an international level, coverage for the risk of sickness evolved towards two basic models in the long term. ${ }^{\text {II }}$ One was that which is now in force in the majority of western European countries, where the compulsory state system took on a dominant role in the medium term. The other is that championed by the United States, based on voluntarism and the free functioning of the market. Recent research into social and economic history has suggested that, while in Europe the alternative networks of voluntary cover collapsed, making the compulsory state system necessary, in the United States the social demand for a public system was mitigated by the presence of relatively wellfunctioning industrial sickness funds providing broad coverage.

Finally, the Spanish seguro obligatorio de enfermedad (compulsory sickness insurance, or SOE) was introduced in 1942 under the influence of the fascist ideology of the Falange, one of the political families comprising the Franco dictatorship. However, it was far removed from the Beveridge Plan that had inspired a large proportion of the state welfare systems in Europe. Within this political context, state health coverage in Spain had some peculiar characteristics. On the one hand, the compulsory sickness insurance started up with serious organizational and financial difficulties, as it did not receive state financing but instead depended on the contributions of employers and

Widowhood, and Uneployment in the Netherlands", in Harris and Bridgen, Charity and Mutual Aid, pp. 89-1 30 .

I I. George Emery and C. Herbert Emery, A Young Man's Benefit: The Independent Order of Odd Fellows and Sickness Insurance in the United States and Canada, I860-1929 (Montreal, 1998); Beito, From Mutual Aid; Bernard Harris, The Origins of the British Welfare State: Society, State and Social Welfare in England and Wales, I 800-1945 (Basingstoke, 2004); Murray, "Persistence of the Health Insurance Dilemma"; Henri Hatzfeld, Du pauperisme a la Securité social I850/1940. Essai sur les origins de la Securité Social en France (Nancy, 1989). 
workers. On the other hand, the Francoist state healthcare system completely ignored the work carried out by friendly societies in the field of healthcare, which effectively led to their virtual disappearance.

Taking the above as a starting point, this article poses the following objectives. Firstly, it intends to analyse the evolution of sickness risk coverage in Spain from i 880 to I944. Secondly, it intends to analyse the factors which led to the "peculiarity" of the case of Spain with respect to the two models of healthcare coverage normally established in pertinent literature. In other words, why did the mixed economy of welfare remain in force for so long in Spain in the field of healthcare coverage? Was it due to the viability of voluntary systems or due to the absence of a state system? In order to deal with these questions, the paper is organized as follows.

The first section analyses the mixed economy of welfare in Spain before the Spanish Civil War. During this period, the state did not manage to meet workers' needs with regard to healthcare coverage. Neither the restructuring of public charity nor the state's tentative and exiguous intervention in matters of social insurance were sufficient. Private insurance companies also failed to meet these needs due to their limited capital, uneven geographical concentration, and scant actuarial development. Within this context, the formula of friendly societies was the one to achieve the greatest development and geographical extension and provided, on the basis of solidarity, significant sickness coverage for a good many Spanish workers bereft of other possibilities of coverage for social risks.

For this reason, the second section of this paper focuses on social coverage against sickness through mutual solidarity before the Civil War. Friendly societies provided medical and pharmaceutical coverage (and at times, coverage for certain specialities such as surgery, maternity, or dentistry) from I 880 until the military coup of 1936 that degenerated into civil war. The triumph of the rebels and the establishment of the Franco dictatorship led to the appearance of a new fascist-influenced social policy, which modified the state's role in terms of social coverage and established a system of social insurance far removed from those in force in other Western European countries.

The third section analyses the process of introducing compulsory sickness insurance under the Franco dictatorship, the characteristics of this insurance and the parallel disappearance of the friendly societies in Spain. The final section sets forth the main conclusions.

THE MIXED ECONOMY OF WELFARE IN SPAIN BEFORE THE SPANISH CIVIL WAR (1936-1939)

As in other capitalist countries, at the beginning of Spain's industrialization in the nineteenth century, sickness risk coverage came from 
four basic sectors: the state, the market, family companies, and solidarity among workers. ${ }^{\text {I2 }}$ However, in Spain prior to the Civil War, both the state and the market played very weak roles, unlike other European states or the private insurance market in the United States. This consequently obliged the friendly societies to assume a more active role, despite their limited effectiveness and their inability to provide sufficient coverage. In the following paragraphs we will analyse the factors which caused the tardiness of state intervention and the apathy of the market, aspects which were to justify, to a large extent, the continued survival of the friendly societies.

With regard to the state, during the nineteenth century the liberal state in Spain had undertaken a reorganization of charity by concentrating it specifically on those who were included in the census of the poor, with the rest of the population having no entitlement to public healthcare. In I883 the Commission for Social Reform was created in Spain, charged with the responsibility for studying social problems and drawing up bills in order to submit them for debate in the Cortes (the Spanish Parliament). ${ }^{13}$ However, these studies did not result in any specific legal provisions and successive governments continued to adopt a passive role with respect to social intervention. At the beginning of the twentieth century there was still great controversy in Spain about what role the state should play in social welfare. The debate gave rise to two opposing tendencies: those who were in favour of state intervention and those who rejected the need for social legislation and even denied the existence of the social question, arguing that it was simply a collection of individual conflicts.

The first welfare model to be applied took place in a context of political instability, a high cost of living, rising unemployment, and growing social protests by workers. Two institutions played key roles in this change of policy: the Institute for Social Reform (Instituto de Reformas Sociales or IRS) and the National Welfare Institute (Instituto Nacional de Previsión or INP). ${ }^{14}$ The former, created by Royal Decree on 23 April I903, was founded with the aim of preparing work-related legislation in the widest sense, monitoring its implementation by organizing the necessary inspection and statistical services, and promoting social and governmental action aimed at bringing about improved conditions or welfare for the working classes. In reality, the Institute for Social Reform became the driving force behind work-related legislation and opened the way for the

I2. For an interesting reflection about the mixed economy of welfare and the historiography of welfare provision, see Harris and Bridgen, Charity and Mutual Aid, pp. I-18.

I3. For more on these aspects, consult Santiago Castillo (dir.), Solidaridad, Seguridad, Bienestar. Cien años de protección social en España (Madrid, 2008).

14. Juan I. Palacio Morena, La institucionalización de la reforma social en España, I883-1924.

La Comisión y el Instituto de Reformas Sociales (Madrid, 1988), and idem, La construcción del Estado Social (Madrid, 2004). 
progressive incorporation of Spain into the European framework in this field. Meanwhile, with a law passed on 27 February 1908, the National Welfare Institute was created, which signified the real start of state intervention in the area of social insurance. From the very beginning there was an attempt to give the National Welfare Institute total autonomy to save it from the vicissitudes of politics. For this reason, it was created as a distinct administrative entity with its own funds, independent of the state, with which to run all the administration related to social welfare. The creation of these two bodies highlighted a change in state policy behind which lay a change of mentality in the political and social structures of the country, as charity (through which only scant results had been obtained) stopped being given priority, giving way to social assistance.

The first state intervention in terms of social insurance was not until I 900 when a law related to industrial accidents was passed, which authorized voluntary insurance. Further, in I919 the first compulsory pension insurance was launched. Intervention in the issue of healthcare did not come until much later. Maternity insurance was not approved until 1929. State provision of public healthcare on a national scale remained unchanged throughout the entire nineteenth century and then up until the Spanish Civil War, although meanwhile the provisions of other public authorities increased, basically at a provincial and, above all, municipal level. Until the Second Republic (193I-1936), public healthcare was dispersed in various partial ways (the fight against infant mortality, tuberculosis, and venereal diseases, and the provision of specialized sanatoria under the responsibility of different institutions). The public healthcare infrastructure was consequently uncoordinated and focused on the poor or on specific targets (especially contagious diseases), and did not address the everyday healthcare needs of the population. ${ }^{\text {Is }}$

During the transforming first two years of the Second Republic, from I93 I to I933, there was nevertheless a notable change of policy as professionals and intellectuals were brought into the government, and who tried to crystallize a healthcare reform in Spain. One of the clearest symptoms of this attempt was the increase in the budget allocated to the Directorate General for Healthcare (Dirección General de Sanidad) which more than tripled in three years, from 9.9 million pesetas in $193 \mathrm{I}$ to 3 I million in 1933 . The attempts to introduce compulsory sickness insurance in this context did not originate so much from the effects of the prevailing economic crisis, but rather from the arrival of politicians open

I5. José Álvarez Junco, "Introducción”, in Ministerio de Trabajo y Asuntos Sociales (ed.), Historia de la acción social pública en España, pp. 9-23; Mercedes Gutiérrez, "Crisis social y asistencia pública en el último cuarto de siglo", in Ministerio de Trabajo y Asuntos Sociales, Historia de la acción social pública, pp. I6 I-I91; Marianne Krause, "La legislación sobre beneficencia y su práctica en el cambio de siglo", in ibid., pp. 193-238. 
to healthcare reform. However, they could not put their plans into practice due to high costs, considerable organizational difficulties, and the opposition of important pressure groups including, above all, doctors and employers. ${ }^{16}$ In the elections of November 1933 the conservative parties grouped within the Confederación Española de Derechas Autónomas (CEDA) came to power, initiating the period known as the Republican "black biennium" (1933-1935). One of their main concerns was to dismantle the preceding body of reforms which they considered to be, in social and religious terms, pernicious to Spain's interests. ${ }^{17}$

Although advances were made in social policy during the Republican period (193I-I936), notably during the first two years of progressive government, sickness insurance continued to be an unresolved issue, as a whole series of factors persisted which hindered its effective implementation. The most serious of these obstacles was the lack of modernization of the fiscal system, which made it difficult for the state to increase its income through direct taxation. This consequently impeded the creation of the infrastructure necessary to provide sickness insurance for the entire population. Further, there remained continued opposition from the majority of employers, doctors' professional associations, mutuals, and insurance companies, who felt their private business interests to be at risk. Even workers showed themselves to be unwilling to accept insurance based on contributions, as they were hoping for greater state coverage without having to make contributions, as was the case with old age pensions. ${ }^{18}$

In spite of all the problems, the socialist Minister of Labour, Largo Caballero, tried to get a project for sickness insurance underway during

I6. The impact of the Great Depression was not especially profound in the case of Spain. Although the contraction of international trade was detrimental to its main export sectors, the impact turned out to be less for Spain than for other countries due to its relative economic backwardness and its lesser degree of participation in foreign markets; Carreras and Tafunell, Historia económica de la España, pp. 252-255.

17. CEDA emerged as an alternative to the first governments of the Second Republic (193I-1936), and it set itself up as the voice of those who did not feel represented by this republic. It brought together forces that defended the confessional state and an anti-socialist vision of political action (monarchists, Catholics, conservatives, and even groups that were close to fascism), and became an instrument of the great agricultural landowners and industrialists. The majority of its members supported the coup d'état against the Second Republic in 1936. Also, see the work of Josep Bernabeu Mestre, "La utopía reformadora de la segunda republica: la labor de Marcelino Pascual al frente de la Dirección General de Sanidad, I93 I-1933)", Revista Española de Salud Pública, 74 (2000), pp. I-I3. This article highlights the important role played by Marcelino Pascua, doctor and Director General of Health from April i93 I until May 1933, and his interest in introducing sickness insurance for large sections of the population. 18. This is what had happened when maternity insurance was introduced, which also led to many cases of resistance from workers. For an analysis of the strikes and disputes in response to the introduction of this insurance in Catalonia, see INP, Informe sobre el seguro de Maternidad (Madrid, 1932), pp. 22-23. 
the first two years of the Republic. The bureaucratic process became drawn out, as the political make-up of the government changed during the second two-year period of the Republic. Finally, the project was presented at the beginning of 1936 under a new progressive government, but was now included within in a wider scheme that intended to bring about the unification of all the different types of social insurance. The main objective was to incorporate Spain into the European trend, which advocated integrated and universal insurance. The outbreak of the Civil War, however, prevented the passage of this legislation. ${ }^{19}$

With respect to the market, unlike countries such as the United States where insurance companies took over from sickness funds when these went into crisis, the private coverage offered in Spain was very exiguous, with many small companies, holding minimal capital and providing cover within a very limited geographical area, mainly concentrated in Catalonia. ${ }^{20}$ The new private insurance law of May 1908 exempted friendly societies without a fixed subscription which only operated on a local, municipal, or provincial scale. This exception allowed them to continue operating without the requirement for deposits or reserves. In I9I 4 this exemption was conceded to 438 friendly societies providing sickness coverage, rising to 443 in I9I 5 . Within this group, there were respectively 207 and 229 mutuals that provided aid in the case of death, as well as in the case of sickness. ${ }^{21}$ Likewise, the private insurance law established that insurers which covered the cost of funerals in exchange for fixed regular fees were also exempted from the law. Only those which provided actual sickness insurance (that is, the provision of medical-pharmaceutical attention and sickness benefit for the head of the family) had to enrol in the register created by the private insurance law. The majority of registered institutions in the market which operated in the sector of sickness insurance were, therefore, medical-pharmaceutical igualatorios (doctors' associations) or specialized medical centres located in Barcelona or in the region of Catalonia, whereas in the rest of Spain insurers were largely dedicated to providing funeral insurance.

The number of institutions registered as authorized bodies in the branch of insurance covering sickness was far less than the number of those exempted, in spite of the fact that the requirements for deposits and

19. For sickness insurance and its debate in the Second Republic, see Isabel Porras Gallo, "Un foro de debate sobre el seguro de enfermedad: las conferencias del Ateneo de Madrid en I934", Asclepio. Revista de historia de la medicina y de la ciencia, 5 I (1999), pp. I59-184.

20. Frank R. Dobbin, "The Origins of Private Social Insurance: Public Policy and Fringe Benefits in America, I920-1950”, American Journal of Sociology, 97 (1992), pp. I4 I6-1450; John E. Murray, Origins of American Health Insurance. A History of Industrial Sickness Funds (New Haven, CT [etc.], 2007).

21. Jerònia Pons Pons, Las estrategias de crecimiento de las compañias de seguros en España (1900-1940), Documento de Trabajo 2202/I (Madrid, 2002), p. 343. 


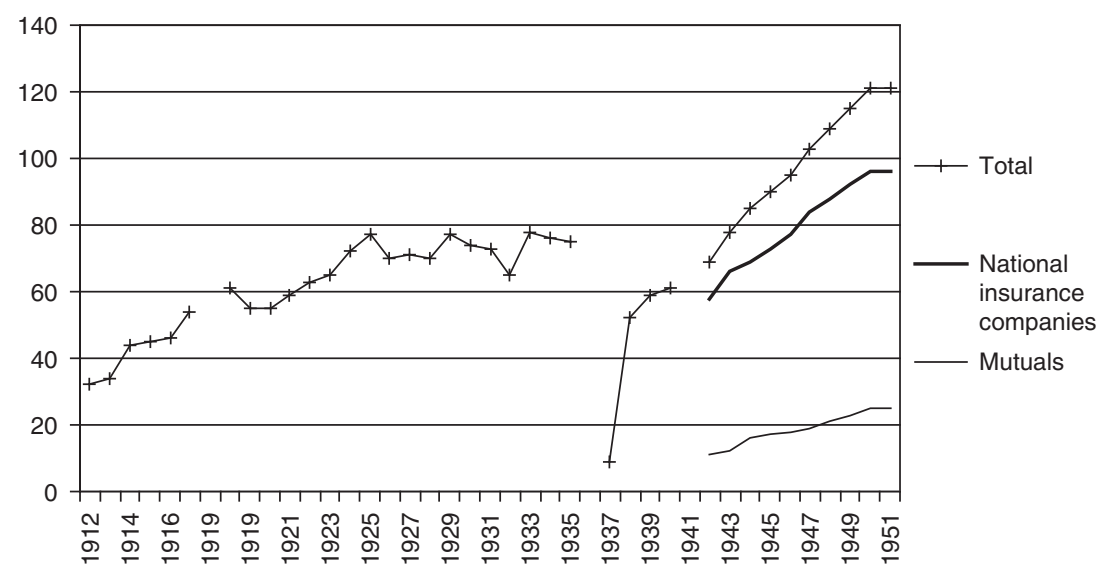

Figure I. Number of institutions operating in sickness and funeral insurance. Sources: Memoria de 1951, Memoria del ejercicio de 1960; Dirección General de Banca, Bolsa e inversions

reserves were low compared with other branches. In I9I 2, there were only 32 companies operating in the areas of sickness and death insurance, all of them Spanish. The top 5 companies together accounted for 68 per cent of premiums. The number of companies rose until it reached 75 in I935 (Figure I). The effect on the already fragmented market was a reduction in the concentration of premiums. While in I9I2 the top 5 companies had a concentration of 68 per cent of premiums in this branch, by 1920 this figure was down to 49 per cent, by I930 it was 33 per cent and after the Civil War, in I940, it was 4I per cent. ${ }^{22}$

The source does not furnish information about the number of policies or persons insured. Nevertheless, simply by observing the premiums, the minimal role which the sickness branch played in the business of private insurance is evident. It can also be seen that rather than increasing its weight over time, this actually diminished. During the entire period from I9I 2 to 1940, the premiums for the sickness branch never exceeded 6 per cent of the total premiums for the entire private insurance companies. With the passing of the years its weight gradually declined until it was a mere 2.85 per cent in I935 (see Table I). There was only a minimal growth in premiums during the I930s, after the disappearance of the sole traders in the sector.

This stagnation of premiums may demonstrate that, despite the slowness of the process of the state adopting sickness insurance, the alternative 
Table I. Private insurance: premiums in the sickness branch. I9I2-I940 (in pesetas)

\begin{tabular}{|c|c|c|c|c|}
\hline Year & $\begin{array}{l}\text { Sickness } \\
\text { insurance } \\
\text { premiums }\end{array}$ & $\begin{array}{l}\text { Index of } \\
\text { premiums } \\
\text { collected }\end{array}$ & $\begin{array}{l}\text { Total } \\
\text { premiums direct } \\
\text { insurance }\end{array}$ & $\begin{array}{l}\text { Sickness premiums as \% } \\
\text { of premiums of private } \\
\text { insurance sector }\end{array}$ \\
\hline 1912 & $6,035,248$ & 55.6 & $116,404,793$ & 5.18 \\
\hline 1913 & $7,040,648$ & 64.8 & $128,990,883$ & 5.45 \\
\hline 1914 & $7,777,412$ & 71.6 & $130,022,459$ & 5.98 \\
\hline 1915 & $8,400,608$ & 77.4 & $138,084,761$ & 6.08 \\
\hline 1916 & $8,138,463$ & 75 & $135,754,263$ & 5.99 \\
\hline 1917 & $7,749,124$ & 71.4 & $129,074,229$ & 6.00 \\
\hline 1918 & $7,362,876$ & 67.8 & $128,409,083$ & 5.73 \\
\hline 1919 & $6,717,837$ & 61.9 & $129,207,297$ & 5.19 \\
\hline 1920 & $6,924,477$ & 63.8 & $135,120,025$ & 5.12 \\
\hline 1921 & $7,921,222$ & 73 & $173,796,842$ & 4.55 \\
\hline 1922 & $9,025,913$ & 83.1 & $179,430,072$ & 5.03 \\
\hline 1923 & $9,472,512$ & 87.3 & $185,347,468$ & 5.11 \\
\hline 1924 & $10,038,525$ & 92.5 & $200,048,002$ & 5.01 \\
\hline 1925 & $10,461,865$ & 96.4 & $210,108,564$ & 4.97 \\
\hline 1926 & $8,565,239$ & 78.9 & $225,811,039$ & 3.79 \\
\hline 1927 & $8,940,369$ & 82.4 & $233,160,016$ & 3.83 \\
\hline 1928 & $10,849,758$ & 100 & $261,798,679$ & 4.14 \\
\hline 1929 & $12,346,784$ & 113.7 & $302,793,081$ & 4.07 \\
\hline 1930 & $13,826,690$ & 127.4 & $323,756,052$ & 4.27 \\
\hline 1931 & $14,262,450$ & 131.4 & $336,510,017$ & 4.23 \\
\hline 1932 & $11,307,900$ & 104.2 & $351,684,561$ & 3.21 \\
\hline 1933 & $12,621,042$ & 116.3 & $412,900,498$ & 3.05 \\
\hline 1934 & $11,002,996$ & 101.4 & $418,199,950$ & 2.63 \\
\hline 1935 & $12,297,390$ & 113.3 & $428,251,722$ & 2.87 \\
\hline $1937^{*}$ & 961,859 & 8.8 & $112,851,052$ & 0.85 \\
\hline 1938 & $10,575,259$ & 97.4 & $211,031,420$ & 5.01 \\
\hline 1939 & $6,018,926$ & 55.4 & $240,970,671$ & 2.49 \\
\hline 1940 & $7,302,478$ & 67.3 & $356,543,117$ & 2.04 \\
\hline
\end{tabular}

Source: Boletín Oficial de Seguros (1913-1926); Boletín Oficial de la Inspección Mercantil y de Seguros (I927-I928); Revista de Previsión (I929-I934); Boletín Oficial de Seguros y Ahorro (I934-I94I); Anuario Estadístico de España (I919). We have data for 1936 but only very partial. In 1937 only the premiums for the part of Spain controlled by the Nationalists are taken into account.

was not to come from a market which remained apathetic and lacking in dynamism throughout the entire period prior to the Civil War. The majority of companies were small-scale, with a limited geographical area of operation, little capital, and run by professional doctors and nonprofessionals from the insurance sector. In contrast to countries like the United States, where insurance companies took over from mutual sickness funds, Spanish insurance companies did not have this capacity. Two factors could explain this lack of capacity. One of these was the underdevelopment 
of actuarial techniques. ${ }^{23}$ The other was the exiguous demand for capital, reserves, and deposits in the sickness branch, which did not favour either the capitalization of these companies or their concentration. ${ }^{24}$ At the same time, both friendly societies and commercial companies offering healthcare coverage to the market concentrated their services on urban areas. In rural areas, healthcare remained linked to the doctors who had established practices in these locations. These doctors, besides taking responsibility for the medical care of those included in the census of the poor, also offered private cover to the rest of the population in return for payment by means of a system of agreed retainer fees (known as igualas). This service, however, did not include any pecuniary compensation and lacked the provision of services in medical-surgical specialities. ${ }^{25}$

Apart from private insurance companies, there were other alternatives offered by employers and particularly by large companies. Large companies, however, were hardly the norm in Spain, whereas small workshops and family concerns were much more common, and for this reason the health coverage paid for by companies usually only benefited a small number of workers. Only in some industrial zones, with a certain concentration of medium-sized and small companies, did workers manage to obtain an employer's contribution to the cost of the sickness coverage, thanks to the strength of the trade unions. Similarly, workers in large companies managed to get their employers to offer them higher benefits than those provided by the state. ${ }^{26}$ During the I920s, the electricity companies in Madrid created a medical-pharmaceutical mutual society for members. In Bilbao, the iron and steel companies and the paper company, Papelera Española, did likewise. Meanwhile, among textile manufacturers in some parts of Catalonia such as Sabadell and Mataró, employers provided maternity benefits that were higher than those

23. Murray, Origins of American Health Insurance, p. 224. In Spain, meanwhile, the study of actuarial sciences was not introduced into business schools until I9I5; Jerònia Pons Pons, "Multinational Enterprise and Institutional Regulation in the Life-Insurance Market in Spain, I880-1935”, Business History Review, 82 (2008), pp. 87-I I4.

24. In 1927 , the Royal Decree Law of 18 February modified the initial deposits required to operate in each sector of private insurance. In the life insurance sector, the deposit was fixed at 500,000 pesetas. The sickness insurance sector, however, had a deposit fixed at the paltry sum of 5,000 pesetas. These exiguous requirements permitted the existence of small companies with minimal capital.

25. Esteban Rodríguez-Ocaña, "La asistencia médica colectiva en España hasta 1936", in Ministerio de Trabajo y Asuntos Sociales, Historia de la acción social pública, pp. 32 1-359.

26. Anna M. Aubanell, "Bienestar industrial en la empresa eléctrica madrileña en el primer tercio del siglo XX", in Antonio Florencio, Carlos Arenas, and José I. Martínez Ruiz (eds), Mercado y organización del trabajo en España (siglos XIX y XX) (Seville, I998); Anna M. Aubanell, "La gestió laboral de l'empresa eléctrica madrilenya en el primer terç del segle XX: els programes de benestar industrial”, Recerques, 37 (1998), pp. I37-164. 
offered by the state, and which allowed women working in the sector to accumulate both benefits. ${ }^{27}$

However, this type of solution proved to be limited due to the generally small scale of companies in Spain prior to the Civil War. For the most part, workshops still tended to predominate over factories at this time, and traditional methods of craftsmanship were still common in the productive process. $^{28}$ On many occasions, employers' contributions were made through friendly societies. At times, therefore, solidarity among workers and the contribution of employers actually complemented each other. In fact, until 1939, the cover provided by friendly societies was still the most viable system for Spanish workers, given that neither the market nor the state offered realistic alternatives. In the following section we will concentrate our analysis on the development, scale, and characteristics of the friendly societies as the only viable alternative for the majority of Spanish workers, apart from private charity or the stigmatizing public charity.

\section{SOCIAL COVERAGE AGAINST SICKNESS THROUGH MUTUAL SOLIDARITY PRIOR TO THE SPANISH CIVIL WAR}

Mutual aid against the contingencies of death or sickness has a long historical tradition, from the confraternities or brotherhoods of medieval origin through to the networks of guilds typical of the Old Regime. ${ }^{29}$ Under the new rules of capitalism, protection based on solidarity took on a new lease of life in the second half of the nineteenth century, both in Europe and in America, where basic common traits can be found within a reality full of nuances. Its progression was basically in response to a growing need of workers to be insured against the social risks which accompanied industrial development in a context characterized by market shortcomings and the passivity of the state in the field of social welfare.

After having overcome a first stage marked by mistrust, the majority of European nations such as Britain, France, and Italy established legal frameworks to regulate the activities of friendly societies, which contributed to their development. ${ }^{30}$ However, in other countries such as

27. Eulalia Vega, "Mujeres y asociaciones obreras frente al Seguro Obligatorio de Maternidad durante la Segunda Republica”, in Cristina Borderías (ed.), Género y politicas del trabajo en la España contemporánea, $1936-1939$ (Madrid, 2007), p. 263.

28. Álvaro Soto Carmona, El trabajo industrial en la España contemporánea, ${ }_{1874-1936}$ (Madrid, 1989), p. 67.

29. A. Rumeu de Armas, Historia de la Previsión Social en España (Barcelona, 1981).

30. See Margarita Vilar Rodríguez, "La cobertura social a través de las sociedades de socorrro mutuo, I839-1935. ¿Una alternativa al Estado para afrontar los fallos del mercado?”, Proceedings of the XVIth Meeting of Public Economy, Financial Crisis and Public Sector (Granada, 2009), CD Rom. 
Spain, relations between friendly societies and the state were incapable of overcoming historical suspicion and mistrust. ${ }^{3 \mathrm{I}}$ The Spanish authorities feared that friendly societies could serve as a front for the labour movement, considered to be a threat to the success of the liberal project. Institutional fears and suspicions led to very strict measures for inspection and control, which clashed with the unwillingness of workers' associations to furnish information, employed as a defensive strategy in hostile circumstances.

In spite of the difficulties, the phenomenon of mutual benefit societies became widespread in Spain. Generally speaking, these were associations funded autonomously by workers on their own initiative, although some were also to be found sponsored by patrons and supporting members, and had the coverage for the risk of sickness or death as their main aim. ${ }^{32}$ Very few workers' friendly societies had sufficient financial capacity to offer cover for old age or permanent disability; risks that demanded a significant expenditure over a prolonged period of time. Furthermore, situations which derived from misconduct (drunkenness, venereal diseases, fights, etc.), catastrophes, and epidemics were always excluded from the coverage provided by friendly societies. The administration of these societies was the responsibility of the members themselves, who took it in turns to sit on the board of directors. The lack of professionalism in this area led to methods based on empiricism and lacking in actuarial rigour. These organizations never used actuarial methods, nor did they set their premiums on the basis of mortality tables which, nevertheless, were used by insurance companies for their life policies. In most cases a general subscription fee was established for all members, both young and old, or rough differences were established in the contributions according to age group, but not calculated in a scientific manner.

One of the keys to their success was the confidence that members had in their society. Consequently, it was normally preferred to limit the number of members per society in order to guarantee their individual control and to facilitate inspection services. The average size of friendly societies in Spain ranged from 100 to 250 members. In general, three basic requirements were necessary in order to become a member: to be presented by two or more members of the society in order to ensure a selective recruitment; to pass a

3I. This led to an administrative silence, which effectively left mutual activity under the generic umbrella of the Law of Associations of i 887. The lack of a specific legal framework did not favour the development of the friendly societies. See Martín Valverde, "La formación del Derecho del Trabajo".

32. Santiago Castillo (coord.), Solidaridad desde abajo (Madrid, 1994). Spanish emigrants extended the phenomenon of mutual solidarity to Latin America and the Spanish colonies. Their influence was to be crucial in the appearance of the first friendly societies, with characteristics similar to those in Spain, notably in Argentina, Uruguay, Cuba, and the Philippines. Also see Pere Solà i Gussinyer, "El mutualismo y su función social: sinopsis histórica", CIRIEC, 44 (2003), pp. 175-198. 
Table 2. Distribution of insured in mutual societies according to risks covered (percentage)

\begin{tabular}{lrrr}
\hline Benefit contracted & 1915 & 1920 & 1925 \\
\hline Sickness cash benefit & 35.25 & 36.70 & 36.56 \\
Medical and pharmaceutical attention & 17.98 & 15.69 & 13.51 \\
Death expenses & 19.02 & 21.86 & 22.65 \\
Disability & 12.30 & 12.22 & 11.86 \\
Funeral expenses & 7.58 & 5.75 & 7.41 \\
Maternity & 1.12 & 1.33 & 1.47 \\
Old age & 3.08 & 2.49 & 2.72 \\
Widowhood and orphanhood & 2.94 & 1.72 & 1.52 \\
Others & 0.73 & 2.25 & 2.30 \\
Total & 435,123 & 798,744 & $1,048,027$ \\
\hline
\end{tabular}

Source: INP, La cuestión del seguro de enfermedad, p. ror.

medical check-up with the society's doctor and; to not be more than a maximum of around 40 to 45 years old. Some societies also charged a small entrance fee as a guarantee of the savings capacity of the member.

Once their application was accepted, members were committed to paying a monthly contribution, either standard or proportional to age, although there was a qualifying period of around three months before new members could benefit from full rights. In some cases, members could pay an extra fee in order to extend the social cover to their immediate family. In situations prescribed by internal regulations, society members provided aid and mutual support to affected members out of the money in the reserve fund. The most common support mechanisms consisted of the granting of a modest cash benefit, or covering medical and/or pharmaceutical requirements during a limited period of time of less than three months a year.

The rather poor statistics available seem to show that the number of mutual insurance associations in Spain increased from I,274 in I9I 5 to 1,770 in 1925 , providing cover for 143,993 and 398,999 members respectively. ${ }^{33}$ The majority of mutual societies offered sickness risk coverage $(35.3$ per cent in I9I 5 and 36.6 per cent in I925), followed by coverage for death and disability (see Table 2). ${ }^{34}$ From a geographical point of view, the distribution of these societies was very unequal, being concentrated predominantly in the more industrialized regions with a greater weight of urban population and wage-earners (Catalonia, the Basque Country, Madrid, and Valencia). In I925, the resources of insurance mutuals were used to provide cash benefits for sickness (75 per cent), pharmaceutical aid (Is per cent) and medical

33. INP, La cuestión del seguro de enfermedad ante la $X$ reunión de la Conferencia Internacional del Trabajo, Ginebra, mayo 1927 (Madrid, I929), pp. 89, 94.

34. Ibid., p. 99. 
attention (Io per cent). Generally speaking, these associations made agreements for healthcare and pharmaceutical provision with clinics, hospitals, or private sanatoriums, although there were still many that could not even count on the services of a private doctor of their own.

In the first decades of the twentieth century, a debate took place in Spain between the representatives of the friendly societies and the state, primarily with regard to healthcare. The National Conference on Sickness, Disability, and Maternity Insurance, held in Barcelona in 1922, served as a forum for the friendly societies to set out their legal and economic claims. ${ }^{35}$ One of their main complaints was in relation to their lack of legislative protection. In contrast to other European countries where friendly societies benefited from specific legislation, workers' mutuals in Spain continued to function under the generic Law of Associations of i 887. In order to solve this problem, an ambitious preliminary draft law was presented. It contained thirty articles that pursued two fundamental objectives: to provide a more solid legal framework for their operations, and to guarantee their active participation in the incipient system of state welfare.

The text defined a friendly society as a jointly held, non-profit insurance entity, in which all of the members enjoyed equal rights and had equal obligations. The aim was to provide mutual aid, including benefits in cash or kind, paid over a period of time or as a lump sum, with the aim of covering the risks of sickness, disability, old age, death, forced unemployment, widowhood, being orphaned, and other similar risks. The text laid down the conditions required for the constitution, functioning, and dissolution of such societies, as well as establishing some basic statutory principles of a compulsory nature. Furthermore, the document proposed a new mutual organizational structure through the creation of a general register of societies, a compulsory provincial federation that would act as an intermediate body and a governing body (consejo superior) of friendly societies headed by the Minister of Labour or by the President of the National Welfare Institute. In the document's conclusions, the friendly societies demanded recognition of their legitimacy to participate actively in the administration of the future compulsory social insurances which were the theme of the conference.

The proposals rested on two principal factors: the friendly societies' long experience of covering risks, and their capacity to act as a link between the state and workers. ${ }^{36}$ However, both the presentation of the preliminary draft law by the representatives of the friendly societies and its reception by

35. Conferencia Nacional de Seguros de Enfermedad, Invalidez y Maternidad (1922) and the interesting reflection on this document made in Josefina Cuesta Bustillo, "Las Sociedades de Socorros Mutuos en el primer tercio del Siglo XX: Sociedad sin Estado: una relación fallida", in Castillo, Solidaridad desde abajo (Madrid, 1994), pp. 409-422. In this forum the representatives of the Federation of Friendly Societies of the province of Barcelona adopted a leading role.

36. See Conferencia Nacional de Seguros de Enfermedad, Invalidez y Maternidad (1922), p. I6. 
the state were full of contradictions. The former showed their readiness to collaborate with the policy of public welfare but rejected state control of their activities. The state, for its part, publicly acknowledged the important work carried out by the workers' friendly societies in respect of sickness coverage, but then went on to ignore completely their demands through a combination of legislative inaction and an absence of information.

In spite of this failure, the friendly societies continued to maintain their share of the market because their main speciality, sickness coverage, was still not provided either by the state or by private insurance companies. Later, the Spanish government defended the need to introduce state sickness insurance of a compulsory nature in the International Conference on Sickness Insurance held in Geneva in 1927. ${ }^{37}$ At the same time, the Spanish government's representatives at this conference justified the absence of such insurance in Spain on the basis of a number of arguments. Firstly, they pointed out that the majority of Spanish wage-earners had sickness risk coverage through a friendly society or a private insurance company (an over-optimistic vision in view of the reality in the country). Secondly, the Spanish delegation was of the opinion that the segment of the population that lacked resources and possessed an official certificate of poverty ${ }^{38}$ could request medical and pharmaceutical services offered by public charity. The official report noted that just in domiciliary care, municipal charity guaranteed the free provision of medical and pharmaceutical services to 595,I 32 families in I925. Finally, the system of igualas had spread throughout the whole country among those common people who could neither afford insurance nor benefit from charity. ${ }^{39}$ Using these arguments, the government announced that state sickness insurance "would cost the state a great deal of money and would have very little guarantee of success". In line with this philosophy, state responsibility was limited to protecting the public against any abuses or fraud committed by the different funds or societies providing private insurance, whether in terms of healthcare provision or of an economic nature. $4^{\circ}$

But by the late i920s the decline of the friendly societies in Spain was evident and this became irreversible in the I930s. Various factors contributed

37. INP, La cuestión del seguro de enfermedad, p. 47.

38. The certificate of poverty was an official document that local authorities issued to people who did not have any means or any possibility of getting work. Having this paper was indispensable for gaining access to the public health care services offered by charitable institutions.

39. A kind of private insurance that people took out with the doctor and the pharmacist of the locality, by virtue of which the insured paid a very modest lump sum, whether he and his family were ill or not, and the doctor and the pharmacist undertook to provide their services whenever necessary. See INP, La cuestión del seguro de enfermedad, p. 22.

40. The state had three inspection mechanisms: the Civil Governors; the Comisaria General de Seguros; and the Comisaria Sanitaria Central. See INP, La cuestión del seguro de enfermedad, pp. 80, 98; Rodríguez-Ocaña, "La asistencia médica colectiva en España". 
to this demise. Compulsory insurance in Spain received a considerable boost during the Primo de Rivera dictatorship (1923-1930), specifically old-age and maternity cover. This process reduced the scope of the activity of insurance mutuals, which subsequently specialized more in providing sickness coverage. Meanwhile, the internal cost structure of the friendly societies underwent important changes in the decades prior to the introduction of compulsory sickness insurance during the Franco regime (1939-1975). Sickness and death benefits lost weight in the total annual expenditure, due to increases in personnel costs and, above all, medical fees. By way of example, the evolution of the expenses of the friendly society known as Montepio de La Caridad (I857-I95I) can be seen in Table $3 .{ }^{4 \mathrm{I}}$

From I90I to I9I9 the largest share of expenditure was on sickness benefits and medical fees, which comprised almost 70 per cent of the total..$^{42}$ However, these benefits remained unchanged in the long term, as there was no significant increase in the daily rate, and they ended up losing weight within the society's total expenditure. By the I940s these benefits only comprised between 10 and is per cent of the expenditure. Medical fees, on the other hand, which only constituted one-third of expenditure at the start of the century, were in excess of 50 per cent by the I 930 s and went on to reach almost 60 per cent of total expenditure in the I940s, before their elimination in 1947. This increase was partly due to the incorporation of specialists, as the services of midwives and dentists were added during the I920s. However, maternity cover was eliminated with the introduction of compulsory maternity insurance in I93 I. The cost of medical fees rose during the Second Republic and especially during the early postwar years, when medical associations approved substantial salary increases. These pay rises coincided with the passage of the compulsory insurance law, which finally brought an end to the provision of medical services by most friendly societies. However, in spite of the fact that it is not perceptible in an analysis of expenses of the societies studied, there are reliable sources to indicate that during these years, medical advances and the application of new treatments and medicines (sulphonamides etc.) pushed up pharmaceutical costs, upsetting the balance sheets of the mutual societies. ${ }^{43}$

4I. Similar trends can be seen in the distribution of expenses of the Majorcan company La Protección (191 I-1945) in Jerònia Pons Pons, El sector seguros en Baleares. Empresas y Empresarios en el siglo XIX y XX (Palma de Mallorca, I998), p. 97.

42. Between I9I I and I 920 the benefits of La Protección were I peseta a day for the ordinary sick and 1.75 for those sick with fever. Between 1930 and 1945 the benefits were respectively I. 50 and 0.75 pesetas a day. Aid in case of death was maintained at 50 pesetas from I9I I to 1945. See Pons Pons, El sector seguros en Baleares, p. 95.

43. Margarita Vilar Rodríguez, "La cobertura social al margen del Estado: asociacionismo obrero y socorros mutuos en Galicia (c. 1839-1935)", Proceedings of the IXth International Congress of Spanish Economic History Association, Murcia, 9-I 2 September 2008, CD Rom. 
Table 3. Expenditure of the Montepio de La Caridad (I90I-I950) (percentage)

\begin{tabular}{|c|c|c|c|c|c|c|c|c|}
\hline & Porter & $\begin{array}{c}\text { Sickness } \\
\text { benefit }\end{array}$ & $\begin{array}{l}\text { Death } \\
\text { benefit }\end{array}$ & $\begin{array}{c}\text { Medical } \\
\text { fees }\end{array}$ & $\begin{array}{l}\text { Meeting } \\
\text { place/ } \\
\text { premises }\end{array}$ & $\begin{array}{c}\text { Expenditure } \\
\text { on } \\
\text { medicines }\end{array}$ & Banks & $\begin{array}{c}\text { Other } \\
\text { expenses }\end{array}$ \\
\hline 1901 & 5.05 & 42.87 & 4.21 & 39.50 & 5.05 & 0 & 0 & 3.28 \\
\hline 1903 & 6.07 & 38.20 & 0 & 41.65 & 6.07 & 0 & 0 & 7.99 \\
\hline 1911 & 7.37 & 43.76 & 8.60 & 31.77 & 5.90 & 0 & 0.85 & 1.72 \\
\hline 1915 & 6.19 & 22.58 & 8.26 & 30.40 & 4.95 & 6.15 & 19.42 & 2.01 \\
\hline 1916 & 6.53 & 27.16 & 4.35 & 34.37 & 5.22 & 10.92 & 8.82 & 2.59 \\
\hline 1918 & 4.13 & 44.34 & 8.95 & 27.39 & 3.30 & 7.51 & 0 & 4.35 \\
\hline 1919 & 5.62 & 29.91 & 7.49 & 41.78 & 4.49 & 7.03 & 0 & 3.65 \\
\hline 1920 & 4.96 & 31.92 & 2.76 & 49.02 & 4.02 & 4.32 & 0 & 2.96 \\
\hline 1923 & 4.39 & 19.38 & 4.27 & 58.73 & 4.16 & 7.66 & 0 & 1.37 \\
\hline 1924 & 4.29 & 20.00 & 1.19 & 64.02 & 4.64 & 4.80 & 0 & 1.03 \\
\hline 1927 & 4.09 & 15.90 & 3.41 & 63.60 & 0 & 3.63 & 7.59 & 1.75 \\
\hline 1929 & 4.61 & 10.75 & 4.48 & 63.74 & 0.58 & 3.70 & 10.99 & 1.12 \\
\hline 1930 & 4.93 & 13.20 & 4.79 & 62.30 & 0.51 & 3.74 & 8.99 & 1.50 \\
\hline 1931 & 5.45 & 17.07 & 2.27 & 60.85 & 1.57 & 4.41 & 7.47 & 0.87 \\
\hline 1932 & 5.28 & 17.85 & 4.40 & 58.76 & 2.03 & 3.38 & 7.35 & 0.91 \\
\hline 1934 & 5.65 & 19.30 & 3.92 & 60.74 & 4.70 & 3.46 & 0 & 2.20 \\
\hline 1935 & 6.04 & 15.15 & 2.51 & 61.64 & 1.32 & 2.67 & 5.18 & 5.45 \\
\hline 1936 & 6.33 & 21.40 & 5.27 & 54.22 & 1.56 & 3.51 & 2.34 & 5.34 \\
\hline 1937 & 7.94 & 10.44 & 3.33 & 60.25 & 1.93 & 4.36 & 5.00 & 6.70 \\
\hline 1938 & 7.78 & 11.45 & 6.49 & 57.89 & 2.34 & 2.66 & 8.66 & 2.70 \\
\hline 1939 & 8.30 & 14.39 & 2.30 & 60.06 & 2.29 & 5.70 & 3.46 & 3.46 \\
\hline 1940 & 8.26 & 11.00 & 4.59 & 59.71 & 1.86 & 4.13 & 2.87 & 7.55 \\
\hline 1941 & 7.11 & 14.02 & 2.87 & 47.83 & 7.36 & 12.91 & 4.59 & 3.28 \\
\hline 1942 & 11.26 & 13.72 & 4.38 & 58.87 & 4.38 & 3.40 & 0 & 3.96 \\
\hline 1943 & 11.92 & 10.01 & 0.82 & 65.29 & 5.36 & 4.47 & 0 & 2.09 \\
\hline 1944 & 11.03 & 20.14 & 2.29 & 50.02 & 5.73 & 5.44 & 0 & 5.31 \\
\hline 1945 & 13.74 & 16.02 & 2.86 & 53.20 & 7.22 & 4.02 & 0 & 2.90 \\
\hline 1946 & 13.97 & 14.93 & 2.91 & 50.67 & 8.21 & 7.51 & 0 & 1.77 \\
\hline 1947 & 14.21 & 30.29 & 0.98 & 28.33 & 8.49 & 5.42 & 0 & 12.24 \\
\hline 1948 & 24.98 & 48.70 & 0 & 8.08 & 14.41 & 0 & 0 & 3.80 \\
\hline 1949 & 15.77 & 68.20 & 4.38 & 0 & 8.63 & 0 & 0 & 3.00 \\
\hline 1950 & 25.96 & 48.64 & 5.40 & 0 & 12.98 & 0 & 0 & 6.99 \\
\hline
\end{tabular}

Source: Archivo del Reino de Mallorca, lligall i609/expediente i ı०0.

A number of historical weaknesses made it difficult for societies to confront the serious financial deterioration. ${ }^{44}$ One of these weaknesses was that the financial autonomy arising from the modest contributions

44. For the case of Spain, see the work compiled by Castillo, Solidaridad desde abajo; but also Van der Linden, Social Security Mutualism; Murray, Origins of American Health Insurance; Van Leeuwen, "Historical Welfare Economics"; and Weinbren, "Supporting Self-Help: Charity, Mutuality and Reciprocity" for the international scenario. 
paid by members resulted in a limited capacity for coverage in the face of uncertainty, both in qualitative terms (the type of risk) and quantitatively (the value and duration of the benefit). Friendly society finances generated from the contributions of patrons, supporting members and employers barely reached, on average, 5.83 per cent of the common reserve fund in $1925 .{ }^{45}$ The state, for its part, only granted a small number of subsidies to mutual societies that applied for them. The limited quantity of this aid ruled out the idea of a system of healthcare provision that was privately managed but subsidized by the state. ${ }^{46}$ Further, mutual insurance proved to be extremely vulnerable from three points of view: very little diversification of risk (they usually insured workers with the same occupation); an absence of actuarial techniques (a lack of study of morbidity rates or not using mortality tables for the calculation of premiums) and; extreme sensitivity to economic cycles (the common reserve fund dropped with increased unemployment or pay cuts). Aware of their weaknesses, the friendly societies established strict selection processes for their members and severe behavioural codes were imposed in order to continue as a member. ${ }^{47}$

In the I920s and I930s the friendly societies ran into great difficulties in covering the generational change. The lack of new young members resulted in insufficient revenue to cover the needs of elderly members; those who most needed medical and pharmaceutical attention. The improved living conditions of the population led young people to feel less need to subscribe to a mutual. Young people preferred to start using the savings books issued by savings banks as a precautionary measure against any future contingency, encouraged by the deliberate policy of promoting savings introduced by the Primo de Rivera dictatorship. ${ }^{48}$ Furthermore, younger people considered that it was just a matter of time before the arrival of state sickness insurance, following in the footsteps of old age and maternity cover, and that this would leave the friendly societies without any clear role. The drop in affiliation worsened the financial imbalances and depreciated the cash benefits being offered.

The situation of the workers' mutuals was further aggravated by growing competition from other forms of voluntary protection, such as

45. See INP, La cuestión del seguro de enfermedad, p. I02. In some friendly societies the presence of patrons or supporting members was decisive.

46. Vilar Rodríguez, "La cobertura social a través de las sociedades de socorro mutuo".

47. Beito, From Mutual Aid to the Welfare State, p. 44.

48. The government carried out an intense campaign of commemorative acts and publicity messages in order to promote saving and even established the custom of celebrating a "savings day" every 3 I October, in accordance with the Royal Order of I4 October I925. See Joan C. Maixé [dir.], Margarita Vilar, and Elvira Lindoso, El ahorro de los gallegos. Orígenes e historia de Caixa Galicia (I 876-2002) (Coruña, 2003). 
private insurance companies, employers' mutuals, and various trade unions. ${ }^{49}$ The first two have already been dealt with in the previous section. With regard to the introduction of the "multiple-base system", this entailed the extension of the trade unions' sphere of activity from the traditional struggle over pay and working conditions to the establishment of some of the types of assistance (sickness, unemployment, disability, etc.) provided by friendly societies. ${ }^{50}$ Under this system, trade-union contributions from the affiliated opened the door to two types of cover, which were distributed equally: the caja de resistencia (resistance fund), and the caja de socorro (relief fund). The trade union offered a resistancefund bonus and the defence of workers' rights, although always with a clear ideological commitment and limited benefits.

The incorporation of the multiple-base concept in the organizational systems of trade unions started to be debated in Madrid in 1906, coinciding with the unemployment crisis and the drop in affiliation being experienced by the workers' societies and the UGT (General Union of Workers). ${ }^{5 I}$ Multiple-base was applied fully for the first time in 1908 in the Madrid printing union known as El Arte de Imprimir, birthplace of socialist trade unionism. Some years later, in 1918, the National Graphical Federation agreed to promote the new formula, which was to become a reality two years later. Other trade unions of different ideologies (including the Catholic ideology) followed suit, although not without problems, as the multiple-base concept created some reticence among members as it increased trade-union fees. According to the trade-unionist philosophy, members with the highest wages paid higher fees, but also received greater benefits.

Generally speaking, unions offered the bonus of the resistance fund and the defence of workers' rights, although always with a clear ideological affiliation. For their part, private companies could already count on a specific legal framework and a greater capacity for coverage, and offered

49. Castillo, Solidaridad desde abajo; Elena Maza Zorrilla, "La horizontalidad de las solidaridades. El mutualismo en la España contemporánea”, in Mariano Esteban de Vega (ed.), Pobreza, beneficencia y política social (Madrid, 1997), pp. 73-102; Pons Pons, Las estrategias de crecimiento de las compañias de seguros; Vilar Rodríguez, "La cobertura social a través de las sociedades de socorro mutuo".

50. A trade-union dictionary in the thirties defined the multiple base as "the functional system of the trade unions which, as well as strike pay and, as a complement to this, establishes mutual aid such as that of sickness, unemployment, travel to look for work, disability", see Santiago González Gómez, "La cotización sindical a 'Base múltiple', puerta de integración del mutualismo obrero en el primer sindicalismo socialista madrileño", in Castillo, Solidaridad desde abajo, pp. 437-446. This formula had already been applied in other European countries such as Germany, the United Kingdom, and Belgium.

$5 \mathrm{I}$. The extension of risk coverage, without going as far as the complete multiple base system, was also taken on board by unions of different kinds and ideological leanings from the end of the nineteeenth century onwards; Soto Carmona, El trabajo industrial, p. 303; Castillo, Solidaridad desde abajo, p. 23; and González, "La cotización sindical”, p. 437. 
the guarantee of some small reserves and professional management. In this context, what incentives did the friendly societies offer working-class families to cover their risk of sickness? Entering into the realm of speculation, we can note two main factors: family tradition and geographical proximity. In particular, mutual solidarity had managed to advance among working-class families both in rural and urban Spain during the century before the Civil War, adapting itself with ease to the needs of each productive activity and location. It was even normal to find friendly societies comprised of a small number of members in small or scattered towns.

The majority of the commercial companies operating in the sicknesscoverage segment, however, were located in Barcelona and Madrid. Both cities together accounted for I49 of the 236 insurance companies operating in Spain from I9I 2 to $1940 .{ }^{52}$ Although the private insurance sector in Spain modernized and rationalized between I9I 2 and 1935, there was still a long way to go in order to overcome the fragmentation and scant capital of these companies. For its part, the complete multiple-base system began among the working class of Madrid, but developed very slowly. The restriction of political and trade union liberties during the Primo de Rivera dictatorship (1923-1929) in particular, was not conducive to the spread of this kind of coverage in Spain.

Consequently, until at least 1936, the shortcomings in the system of state provision, especially in the area of sickness benefit, and the limited and unequal regional development of its main competitors, enabled friendly societies to maintain a share of the market, albeit a decreasing proportion. In view of these conclusions, it seems that the provision of sickness coverage by friendly societies survived in Spain at least until the Civil War, more due to the failings of the other means of coverage than to the efficiency of the model itself. Its days, however, were numbered, as state intervention in the sphere of sickness coverage seemed to be inevitable. The state, although moving slowly, had now finally opted for a public system of compulsory state insurance. The process had been initiated with the establishment of old age, maternity, and industrial accident insurance, and therefore it was only a matter of time before sickness insurance would be provided.

\section{THE PASSAGE OF COMPULSORY SICKNESS INSURANCE AND THE DISAPPEARANCE OF THE FRIENDLY SOCIETIES (1939-1944)}

The coup d'état of July 1936 that led to the outbreak of the Spanish Civil War, was aimed at the forceful overthrow of a democratic regime in order

52. Vilar Rodríguez, "La cobertura social al margen del Estado", and Pons Pons, Las estrategias de crecimiento de las compañias de seguros. 
to impose a dictatorship, which marked a break with the past not only in political terms but also socially and economically. The autarkic and interventionist growth model of the Franco dictatorship condemned the country to a long post-war period, characterized not only by spectacular falls in the main economic indicators, but also by an alarming step backwards in terms of education and welfare in a context of the deprivation of human, social and political rights. The figures are conclusive. The 1935 income level of the Spanish economy was not regained until I 5 years later and its convergence in terms of GDP per capita with respect to the principal European countries was reduced to an all-time low in I 960 ( 53 per cent).$^{53}$

After their victory in the Civil War, Francoists also established a regime of social coverage which fitted in perfectly with their ideology. ${ }^{54}$ The dictator did not intend to use social policies as a way of improving the population's welfare or redistributing income more equitably. Quite the opposite - social insurance comprised part of a broader political strategy. On the one hand, the Francoist regime's social insurance served to reduce social tensions in a context of repression and terrible living conditions. On the other hand, these social provisions served the dictatorial regime as a propaganda tool, as they allowed the authorities to present a friendlier face to workers who were being subjected to tough working conditions and a lack of liberties. Within this model, the main source of financing for social insurance was through contributions from companies and workers, while the state's contribution was almost a token gesture. Consequently, benefits remained very low and were few and far between. Sickness insurance became one of the cornerstones of the dictatorship's social propaganda in a Spain, where hunger was still rife and a climate of fear and repression reigned.

There exists a cause-effect relationship between the way sickness insurance was implemented during the first stage of the Franco regime and the disappearance of the friendly societies. These were organizations which had emerged, in most cases, among the working classes and the fascist Francoist dictatorship installed after the Spanish Civil War tried to favour other pressure groups involved in sickness insurance, especially employers' and professional organizations. In fact, the social groups of employers and workers represented the two sides of the social divide that existed in the post-Civil-War period in Spain. The employers, representatives of the winning side, were able to benefit from the support and sympathy of the regime. The workers, linked to the losing side, remained

53. Figure calculated in relation to the European average of twelve (European) countries; Leandro Prados de la Escosura, El progreso económico de España (I850-2000) (Madrid, 2003). 54. Margarita Vilar Rodríguez, Los salarios del miedo. Mercado de trabajo y crecimiento económico en España durante el franquismo (Santiago de Compostela, 2009). 
outside the circles of influence while at the same time they were subject to a hostile labour environment which deprived them of all possible ways of defending their civil rights and maintaining decent living conditions. We will next examine how the process developed.

After years of debate, the government of the Franco dictatorship finally introduced compulsory sickness insurance. Like the entire system of social welfare in force during the post-Civil War period, compulsory sickness insurance served the dictatorial regime as a tool for applying its repressive regime and for exerting control over the workers. ${ }^{55}$ At the same time, this insurance comprised part of the paternalistic social propaganda that the regime tried to exploit as a way of legitimizing its power and eliminating any social or labour tensions and disputes. ${ }^{56}$

Although Franco concentrated all power in his hands, in practice he delegated decision-making to the heads of different departments, controlled by the numerous "political families" of the regime (military officers, Falangists, monarchists, Catholics, and technocrats) who struggled to gain a greater share of power. Internal disputes gave rise to inconsistencies and difficulties of coordination in different areas. ${ }^{57}$ In particular, control of public healthcare during the Franco regime was in the hands of two principal factions. On the one hand, the National Catholic group controlled the Ministerio de Gobernación (Ministry of the Interior) and the Directorate General for Health. On the other hand, the Ministry of Labour and the bodies responsible for the management of different types of insurance such as the National Welfare Institute were in the hands of the Falange Española de las JONS (the official fascist party). The compulsory sickness insurance was promoted by the latter group and comprised part of their social policy.

The social aspect constituted one of the main pillars supporting the national syndicalist ideology. From their point of view, workers made up part of a unit "in which each part had to be efficacious and contribute their energies towards the aggrandisement of the fatherland". ${ }^{8}$ In line with this philosophy, compulsory sickness insurance was necessary in order to treat sick workers and reintegrate them into the "charming

55. For a wider analysis of the role of the state insurance system in the Francoist regime, see Margarita Vilar Rodríguez, "El sistema de cobertura social en la inmediata posguerra civil (1939-1958): una pieza más de la estrategia represiva franquista”, VI Encuentro de Investigadores sobre el franquismo (Zaragoza, 2006), pp. 619-636.

56. Carme Molinero, La captación de las masas. Política social y propaganda en el régimen franquista (Madrid, 2005); Pedro González Murillo, "La política social del franquismo: el Seguro Obligatorio de Enfermedad", Revista de historia contemporánea, 57 (2005), pp. 62-76. 57. Rafael Huertas García, Organización Sanitaria y Crisis Social en España (Madrid, 1995). 58. Isabel Jiménez Lucena, "Medicina social, racismo y discurso de la desigualdad en el primer franquismo", in Rafael Huertas and Carmen Ortiz (eds), Ciencia y Fascismo (Madrid, 1998), p. I I 2 . 
metaphysical complex which is Spain".59 This spirit pervaded the implementation of compulsory sickness insurance through the institutions controlled by the Falange. However, as the taxation policy that would be necessary in order to finance the future insurance remained outside their control, and also due to the exclusion from the Directorate General for Health of the oligarchies which controlled the healthcare structure, the insurance was born with serious financial difficulties and with a deficient healthcare infrastructure and bureaucracy. ${ }^{60}$

In order to implement compulsory sickness insurance, the state sought the support of the medical organizations, employers, and insurance companies which had opposed its introduction for decades. ${ }^{6 \mathrm{I}}$ The Francoist regime managed to neutralize the opposition, above all that of employers, who accepted the insurance in return for other privileges. Employers were compensated by the introduction of an extremely harsh system of repression of any labour disputes, and also by the possibility of playing a part in administering the insurance. The medical organizations, for their part, were won over by means of the progressive incorporation of their doctors into the staff of the compulsory sickness insurance structure, although the old factions of healthcare workers remained outside this process. ${ }^{62}$

Finally, under the new legislation passed on i4 December I942, "affiliated producers" ${ }^{63}$ with an annual income of less than 9,000 pesetas, were entitled to insurance. The law provided coverage for those working for an employer through healthcare provision in the event of sickness and maternity, and workers' financial compensation for loss of earnings or in case of death. The insurance also covered the family of the insured. A further two years passed before the law was actually put into effect; time which the National Welfare Institute, responsible for organizing and managing the scheme, needed to arrange the healthcare and administrative infrastructure required to implement the insurance. ${ }^{64}$

In order to solve these difficulties, Franco's government issued a decree on 2 March 1944 allowing agreements to be established between the

\section{Ibid.}

60. For the clans and conflicts in the health care institutions during the early years of the Franco regime, see Joan Serrallonga i Urquidi, "El cuento de la regularización sanitaria y asistencial en el régimen franquista. Una primera etapa convulsa, 1936-1944”, Historia Social, 59 (2007), pp. 77-98.

6r. Molinero, La captación de las masas, p. i23. See Rodríguez-Ocaña, "La asistencia médica colectiva en España hasta 1936", p. 35 I.

62. Serrallonga, "El cuento de la regularización sanitaria". One of the main demands of doctors during the Second Republic was that they become civil servants. The Franco regime gave in to this demand; Josep Bernabeu Mestre, "La utopía reformadora de la segunda", p. 6.

63. A euphemism used by the regime to eliminate the idea of a class struggle between workers and employers.

64. Pons Pons, "El seguro obligatorio de enfermedad". 
National Welfare Institute and private collaborating bodies, and on 8 March 1944 the Ministry of Labour issued an order stipulating the regulations for executing the decree. According to this document, the institutions which could apply to partake in the agreement were mutual societies, montepios (similar to friendly societies), companies, and igualatorios, which had organized some kind of health-care service or economic provision for their staff or for affiliated members in the event of sickness. Only 3 I of the 228 organizations that signed agreements with the National Welfare Institute operated on a national scale, while the rest only provided coverage on a local, provincial, or regional level.

The companies which signed an agreement with the National Welfare Institute to manage compulsory sickness insurance included large mining and railway companies (which already ran medical insurance) and also some doctors' associations. The organizations which showed the greatest interest in reaching this kind of agreement, however, were the employers' industrial accident mutuals, which already had an infrastructure of clinics and dispensaries, together with agreements with hospitals, as well as a considerable bureaucracy for managing the insurance. They also had an interest in continuing to exercise direct control over sick workers, as they already did over injured workers. ${ }^{65}$ Among the first employers' mutuals to sign an agreement were those which operated on a national scale, including Mutua General de Seguros, Mutua Balear and Mapfre.

The state did not integrate the friendly societies as a whole into the new healthcare system, although some of them were exceptionally incorporated on an individual basis. These were the most powerful montepios and friendly societies, the majority of which were Catalan and linked to the textile sector, and which had previously converted into insurance mutuals, such as the Montepío textil de Badalona, Asociación de Previsión Social, and the Servicio Mutual Montepío de Empresas de la Industria textil de Hospitalet de Llobregat, Asociación de Previsión Social. ${ }^{66}$ The late intervention of the Spanish government in the provision of sickness coverage prolonged the survival of the friendly societies, which had been losing market share with the introduction of other types of insurance. ${ }^{67}$ For example, the passage into law of maternity insurance in 1929 led to the abandonment of the midwifery service which the friendly societies

65. Andreu Bibiloni and Jerònia Pons, "El desarrollo de las mutualidades patronales de accidentes de trabajo en España. El mercado balear: entre la competencia y la colusión (1920-1940)", Revista de Historia Industrial, is (1999), pp. 83-104.

66. For a list of the agreements reached between I June I944 and 25 October 1945, see Pons Pons, "El seguro obligatorio de enfermedad".

67. This factor is considered to be decisive in the work of Antonio Rivera Blanco, "Desarrollo y crisis del modelo de sociedad de socorros (Vitoria, I849-1938)", in Castillo, Solidaridad desde abajo, pp. 142-143. 
had been offering since the end of the first decade of the twentieth century to women related to members. ${ }^{68}$ From the time that compulsory sickness insurance was first implemented in 1944, almost all friendly societies stopped offering sickness coverage and most of them disappeared or were transformed into social clubs. Exceptionally, a few societies which managed to reach an agreement with the National Welfare Institute continued with their coverage.

The reasons for this limited integration into the state system were basically financial and bureaucratic. According to the decree of 2 March 1944, the collaborating bodies had to establish a guarantee deposit and liquidate the premiums collected on a quarterly basis and forward them to the National Sickness Insurance Fund. In this liquidation, they had to make up the difference between the percentage agreed and the premiums collected, or the difference between the premiums paid by employers and workers, according to the official rate, and that of the provisions of the insurance, from which they could only deduct the amount corresponding to administrative costs. The majority of friendly societies operated on a strictly local basis and it was difficult for them to achieve a financial balance. The low contributions (established solely to cover doctors' costs, pay small benefits and cover the purchase or rental of their premises) did not allow them to accumulate sufficient capital for a deposit, and much less to pay someone to deal with the enormous bureaucratic load which the compulsory sickness insurance entailed. Besides, many friendly societies had already entered into a downward spiral due to other factors previously mentioned.

The majority of friendly societies started to disappear at the time that compulsory sickness insurance was implemented. Understandably, those workers covered by state insurance lost interest in paying additional money for something that the state now provided, and which cost them a significant part of their wages. This was already happening during the first stage of the introduction of compulsory sickness insurance, implemented in I944, when only primary healthcare was covered. After the Decree of 26 December 1946, when the service was extended to general surgery, hospitalization, and a service covering analysis and other diagnostic tests, contributions were further increased. This process was accompanied by an increase in the premium collected from both employers and workers; from a total of 5.0I 3 per cent of the insured's earned income in June 1944 to the 8 per cent it reached in January 1948 .

Compulsory sickness insurance, therefore, was in line with the general approach of the regime to welfare concerns, in that the state did not finance

68. This was the case, for example, of the Montepío de la Caridad, a society founded in Palma de Mallorca in I857 and which operated until 195 I. Two midwives were incorporated into the service in I9I 8 , a provision which continued until 1930. As from I93 I it disappeared from the society's expenses. 
the provision but merely acted as a manager, controlling the application of the law. In the case of sickness insurance, even part of the management of the insurance was passed to the private collaborating bodies to avoid expense to the state. The insured themselves and the employers financed the bureaucracy which resulted from the management of the insurance, as a percentage of the premium was deducted to cover healthcare inspection and the creation of hospitals in accordance with the Healthcare Facilities Plan. This led to the creation of large hospitals known as residencias sanitarias throughout the country. ${ }^{69}$ The distribution of the financial burden of the insurance between workers and employers was naturally very unequal in the context of extremely low labour costs. Consequently, the workers made a greater economic sacrifice than did the employers. ${ }^{70}$

Nevertheless, the first years of the implementation of compulsory sickness insurance did not entail a significant change in the availability of healthcare coverage for the majority of the Spanish population. In reality, it went on to cover the same group, industrial wage earners, as had already been afforded the opportunity of coverage through friendly societies or other market mechanisms. Thus, an important segment of the Spanish population remained without healthcare provision, notably agricultural labourers and the self-employed. In 1944, the beneficiaries of compulsory sickness insurance only comprised 25 per cent of the Spanish population, a percentage which slowly grew but had still not reached 30 per cent by I950: when agricultural labourers comprised 47.6 per cent of the country's working population. ${ }^{71}$ The introduction of compulsory sickness insurance was the final blow to the friendly societies whose decline had begun back in the I920s and I930s. Some did away with the service of providing medical attention, maintained sickness and death benefits, and languished for a time, continuing to provide a social and recreational function. ${ }^{72}$ The majority, however, sold off their assets (usually their head office) and went into liquidation.

In the I950s, after a decade of isolation during the autarkic period, the Franco government tried to establish closer relations with some Latin American countries on the pretext of exporting its social insurance model in order to recover its lost role of Madre Patria de la hispanidad

69. For the regional imbalances in health-care infrastructure which resulted from the management of compulsory health insurance, see Jerónia Pons Pons, "Sickness Insurance in Spain 1908-1963", paper presented at the conference "Insurance, Sickness and Old Age: Past Experiences and Future Prospects?”, held at the University of Southampton, I 5-16 April 2009. 70. Labour costs fell drastically during the post-Civil-War period; see Vilar Rodríguez, "El sistema de cobertura social".

71. Roser Nicolau, "Población, salud y actividad", in Albert Carreras and Xavier Tafunell (coords.), Estadísticas históricas de España, I (Bilbao, 2005), pp. 79-I 54.

72. See the case of the Montepío de Previsión de l'Arraval de Santa Catalina; Fullana and Marimón, Història del "Montepio" de Previsió de l'Arraval. 
(mother country of Spanishness), an idea which constituted part of the dictatorial regime's philosophy. Latin American social security congresses started being held in this context. The first was held in Madrid in I95 I and the second in Lima in 1954. During this second congress an agreement was made to create the Latin American Social Security Organization, with its headquarters in Madrid. Its first president was Carlos Martí Bufill, Technical Secretary-General of the Spanish National Welfare Institute and an expert in Latin American social insurance. ${ }^{73}$ Parallel to this, courses for the training of social security technicians were offered periodically. These courses were run by Spanish civil servants and they fostered visits by top civil servants and other political figures from Latin America. ${ }^{74}$ Contacts were made mainly with Peru, Colombia, Bolivia, and Ecuador; countries which endured dictatorial regimes similar to Spain's, a fact that favoured closer political ties. These countries comprised part of the second wave of South American states that introduced their social insurance programmes during the I940s and I950s, after the pioneering group composed of Chile, Uruguay, Argentina, Cuba, and Brazil. ${ }^{75}$ Collaboration between both sides of the Atlantic in matters of social policy continued until the end of the dictatorship in the mid-I970s.

\section{CONCLUSIONS}

Sickness risk coverage was one of the main concerns of working-class families at the beginning of industrialization. The first models of protection were promoted by workers by means of friendly societies. Later, the development of private insurance companies opened the way to new means of healthcare cover. At the end of the nineteenth century, European states started to implement state systems of healthcare provision with different

73. $A B C$ newspaper, 28 October 1954, p. 29. Carlos Martí, a lawyer by profession, was a senior member of the National Welfare Institute (Jefe Adjunto del Servicio Exterior y Cultural del Instituto Nacional de Previsión) and worked closely with Latin America (Secretario de la Sección de Estudios Sociales del Seminario de Problemas Hispanoamericanos vinculado al Instituto de Cultura Hispánica). He undertook an important body of work as a publicist. Worthy of special mention among his other works on social insurance are those on America: "La Seguridad Social en los Estados Unidos de América", "España y la Seguridad Social hispanoamericana", and "Presente y futuro del Seguro Social" (1948), in which he devotes a chapter to the analysis of social security in Latin America. This was the forerunner of his book "El Seguro Social en Hispanoamérica" published in 1949. One of a number of posts he accepted was that of President of the World Legal Commission on Social Security in 1969. See the biography of the author which appears in the book "El Seguro Social en Hispanoamérica" (1949), and $A B C$, i November 1969, p. 3 I.

74. $A B C, 28$ November 1957 and 3 July 1965.

75. Carmelo Mesa, "History of Social Security in Latin America", International Meeting on the History of Insurance in the World, Fundación Mapfre, Madrid, 8-9 May, 2008. 
characteristics. Some governments incorporated the friendly societies into their welfare programmes while others ignored them. In the latter case the societies only had two options for survival: becoming commercial insurance companies or abandoning healthcare provision and continuing basically in a recreational capacity. Unlike Europe, in the United States the efficient functioning of healthcare provision through private organizations and the pressure they were able to exert in social, political, and economic circles made state intervention more difficult in this area.

As far as sickness insurance is concerned, the Spanish case prior to the Civil War was more akin to the American model than to the European one. During this period the state did not legislate, regulate, or finance healthcare provision, which remained in the hands of mutual societies and private companies. However, unlike the United States, in Spain state passivity did not satisfy the healthcare demands of the population, but this was certainly not in response to the existence of an efficient private system. On the one hand, the Spanish mutuals, financed exclusively through the small contributions from their members, ran into serious imbalances in their finances in the I920s and I930s, especially due to the rise in price of medical fees and medicines. On the other hand, private insurance companies had two serious problems, the backwardness of actuarial techniques and the scant provision of the sickness sector for capital reserves and deposits, which put a brake on the capitalization of companies and their concentration.

The deficient functioning of the private sector and the influence of European models that Spanish governments had already followed in providing cover for old age, unemployment, and maternity, ended up forcing the introduction of state sickness insurance. However, in contrast to democratic Europe, in Spain it was a dictatorial government, unfavourable to workers, that laid the foundations of the system, a fact which conditioned its basic characteristics. As in other areas, the Franco dictatorship laid the cost of the insurance on the workers, who earned very low wages, while at the same time it used the private sector to save itself the expense of management and facilities.

Nevertheless, this system of private management based on contributions left an uneven outcome. In 1950, only 30 per cent of the Spanish population was covered by compulsory sickness insurance, while the rural population, which comprised 50 per cent of the entire population, was still excluded. The majority of the collaborating bodies operating the compulsory sickness insurance had deficits, given that premiums had more to do with political decisions than actuarial criteria, and because part of the premiums had to be deducted for the National Healthcare Facilities Plan and for maintaining the healthcare inspection service. Furthermore, the private management of compulsory sickness insurance resulted in a great regional imbalance in healthcare infrastructure. 
Finally, political changes in the regime itself and the need to improve the cover for the majority of the population led to the passage of the Law of Social Security in I963, which entailed direct state management of the insurance. The majority of the friendly societies, which had been the most viable option for workers before the Civil War, disappeared along the way. Only a few integrated, while others languished in time, devoid of their initial function. 